\title{
Lived Experience: Perceptions of Competency of Novice Teachers
}

\author{
Pauline Swee Choo Goh
}

EdD. Sultan Idris Education University, Malaysia, goh.sc@fppm.upsi.edu.my

Qismullah Yusuf

$\mathrm{PhD}$. Sultan Idris education University, Malaysia, qismullah@fppm.upsi.edu.my

\section{Kung Teck Wong}

PhD. Sultan Idris Education University, Malaysia, thomas@fppm.upsi.edu.my

This study bridges the gap of an outsider-insider perspective of competency and captures the essence of what constitutes competency among 18 novice teachers in their own actions performed in real classrooms. In this study, relevant aspects of the novice teachers' 'lived-experience' in their schools make up their conceptions of competency. Novice teachers' talk about achieving their aims of competency in strategically different ways and in each of these ways, the novice teachers' strategies are critical to their understanding of the novice teacher-student roles. Five identified conceptions are: controls in the classroom and behaviour of students, methodical preparation, uses of sound in pedagogical knowledge and skills, understanding and empowering their students to take charge of their own learning, and an awareness of themselves as teachers. The conceptions of competency are represented diagrammatically and are discussed with respect to levels of complexity. Variation exists in the way novice teachers conceive of their competency. Teacher educators should be cognizant of the diversity in practices of teachers and not limit that to say that there is just one acceptable conception of competency.

Key Words: novice teachers, Malaysian teacher education, conceptions of competency, professional practice, professional engagement

\section{INTRODUCTION}

One of the more complex processes in a teaching profession is learning to teach (Darling-Hammond, Newton, \& Wei, 2013).). The first three years of teaching has an important impact on the future careers of novice teachers worldwide (Stokking, Leender, De Jong, \& Van Tarwijk, 2003). They are not only inundated with the complexities, ambiguities and uncertainties of a teacher's work and of learning to teach but the transition from training institutions to the classrooms in schools can be characterized as a 'reality shock' (Fatiha, Abd Razak \& Shanina, 2013). Similarly, novice teachers' in 
Malaysia are no different. Unfortunately, the competency of a novice teacher is judged almost immediately during periods of their teaching through observations by their school principal as part of their performance evaluation before being confirmed into the teaching profession. It is not surprising that most novice teachers have concerns about being observed and about how they will be judged in the classroom (Goh \& Matthews, 2011). It can be argued that novice teachers are a rather neglected lot and rarely are they asked what constitutes 'competent practice' in their own practice although they are being judged against a set of traditionally 'desirable characteristics' (Admiraal \& Berry, 2015). Internationally, the studies on novice teachers' conceptions of their own competence are very limited (Admiraal \& Berry, 2015) and even less in Malaysia. This study bridges the gap of an outsider-insider perspective of competency and captures the essence of what constitutes competency among 18 beginning teachers in their own actions performed in the real-world teaching environment.

\section{BACKGROUND TO THE STUDY}

Teachers' competency remains an important issue in teaching profession. Most educational stakeholders (e.g. students, parents, educators, and policy makers) believe that the quality of teachers and achievement of pupils in schools are associated with the competency of teachers. Due to the need to numerically measure competency, various procedures have been implemented to make some form of assessments on areas of teacher competence. While educationists in America debate about compulsory teacher evaluation criteria (Darling-Hammond, Newton, \& Wei, 2013), teachers in the United Kingdom and Australia are grappling with the aftermath of teacher evaluation of competence and rising dissatisfactions (Tuinamuana, 2011). Not to be left behind, Malaysia has also developed a set of competency-based teacher standards for the same purpose of evaluating teachers. Rationale for its development is to enable reliable judgements to be made on teacher competence ("Malaysia First in Region to Adopt Benchmark", 2009). This means that teachers are now required to perform and align their teaching practices and actions embellished in the standards to achieve high teaching competency. However, in reality, any universal agreement of the contents of such standards is almost non-existent (Sykes, Bird, \& Kennedy, 2010). Nevertheless, the evaluation process of novice teachers through the competency-based standards remains at the forefront of their 'rite of passage' into the teaching profession.

Generally, novice teacher must serve one to three years as interim teachers before their formal confirmation into the teaching profession. Similarly, in Malaysia, during the first three years, novice teachers are evaluated through a variety of methods, including compulsory attendances and passes at in-service courses initiated by the Ministry of Education and its professional divisions, and on-site performance evaluations. During in-services courses, novice teachers are taken out of their normal school routine. Such courses are believed to enhance their existing skills (Fatiha, Abd Razak, \& Shanina, 2013). Mandatory on-site performance evaluations are carried out by visiting school inspectors, head teachers and principals using a prescribed evaluation standard. It is the latter, the performance evaluations of novice teachers, that is of interest in the study. This mandatory performance evaluation represents a formal judgement of novice 
teachers' competence through an externally constructed definition of teacher competence. This paper argues that consideration should be given to what novice teachers hold as conceptions of competency. After all, if this group of teachers is to be fairly judged, they should be the first to be asked about their own conceptions of competency held by them.

In the arena of teaching profession, many researches have focussed upon empirical measurement of teacher competency through standards and performance indicators (Serafini, 2002). This positivist approach, while perhaps inconsistent with the advocates of non-empirical researchers, emanates from a perceived need to quantify and prove competency in a purely objective way, citing several desirable attributes or task in a world in which benchmarking through statistical means dominates education (Halverson, Kelley, \& Kimball, 2004). However, attaching competency to a predefinition set of standards does not encapsulate a teacher's competence in accomplishing the work, to reflect, to learn and to grow. It does not recognise the important relationship between effective attributes and work activities (Sandberg \& Pinnington, 2009). Such views have been criticised as describing performance rather than competent performance. A thorough understanding of competent performance cannot be achieved through mere statistical judgement, rather, much remains to be learnt about how individuals learn to think, know, feel and act like teachers (Feiman-Nemser, 2008). Therefore, the need for an alternative discourse based in the realities of novice teachers, rather than a discourse of justification based upon monitoring and performance indicators, underpins the phenomenographic orientation of this study.

\section{METHOD}

For this study, a phenomenographic methodology was used as it provided a structured approach to identify and understand the qualitative differences in conceptions of a phenomenon from the perspective of those who had experienced it (Martön and Pong, $2005)$, in this case, the qualitatively different views and teaching practices of participating novice teachers. It allowed the participants to explore their own experiences using open-ended and in-depths interviews and used the total group experience to highlight the various phenomena found within the group. Similarly, according to Martön and Pong (2005), in a phenomenographic investigation, it is the collective understandings of groups rather than the conception of an individual participant that makes up the data. In fact, a participant may reveal multiple conceptions of a phenomenon. Feelings will also vary as the conversation about the phenomenon is discussed (Martön \& Pong, 2005).

\section{Data Collection}

Data was collected through a series of in-depth, open-ended interviews that focused on allowing each novice teachers to fully describe their experiences. The 18 novice teachers were from a teacher education university in Malaysia and had graduated with a degree in education with majors in various academic disciplines. These 18 novice teachers were teaching in various states of Malaysia, namely, the states of Sabah, Sarawak (both states in East Malaysia), Perak, Selangor and Johor (three states in 
Peninsular Malaysia). Novice teachers in this study were defined as those teachers who were still under probation and had not been formally confirmed as a part of teaching profession. As participation was voluntary, the 18 novice teachers had the right to withdraw anytime during the study and their interviews erased. The participants were assured of anonymity and that the interview data collected would be used ethically. The novice teachers were asked questions which probed their understanding of what competency meant, what it took to achieve competency.

The first author conducted all the interviews. All interviews were conducted in the Malaysian language. A research assistant transcribed the interviews verbatim from the audio recording. The transcripts were later checked by the authors. To ensure trustworthiness of the data, each completed transcribed interviews were returned to each of the 18 participant through emails. Each participant was asked to verify the accuracy of the transcripts. Participant checks were used to verify the accuracy of recorded words and the conceptions expressed by the participants and to identify any misunderstandings. The interviews in the Malaysian language were translated into English as best as possible for the purpose of this paper to ensure that the original meanings were not lost. Each novice teachers' interview was given a pseudonym to avoid identification, for example, 'NT' being novice teachers.

\section{Data Analysis}

An iterative approach of checking and repeated reading was used based on four indicators (Larsson \& Holmstrom, 2007): i) check for frequency, that is, how often the phenomenon was uttered; ii) where the utterances and statements were positioned, generally check for 'what' constitutes competency of the novice teachers and 'how' he/she described that understanding of competency; iii) significance, that is when answers explicitly emphasized certain aspects to be more important than others; and iv) the last stage of the phenomenographic analyses involved examining the internal relations between the categories and were referred to as the referential and structural parameters (Larsson \& Holmstrom, 2007). The aims of the teaching competencies were defined as the referential parameter while the strategies used to achieve the competencies were defined as the structural parameter.

\section{CATEGORIES OF DESCRIPTION}

In the analysis of the interviews with novice teachers, five qualitatively different ways of understanding the conceptions of teaching competency were identified. These conceptions are reported below as 'conceptions of competency'. They are: (1) classroom and behavioral management: a competent teacher is in control of the classroom and behavior of students; (2) methodical preparation: a competent teacher is methodical in preparing lesson plans and be well organized in the use of teaching resources; (3) facilitate learning: a competent teacher uses sound pedagogical knowledge and skills; (4) understand and empower students: a competent teacher is able to understand their students and to empower them to take charge of their own learning; (5) awareness of the profession: a competent teacher establishes an awareness of themselves as teachers. 


\section{Conceptions of Competency 1: Classroom and Behavior Management}

Intentions of the novice teachers: This competency relates to the different ranges of appropriate classroom management. Classroom management also entails managing student behaviours to control the learning environment, such as 'control discipline of those students arriving late' (NT2, female) and 'putting in place proper control of classroom to make teaching easier' (NT6, female).

Strategy used to achieve this aim: Novice teachers tell how they manage their classrooms and disruptive student behaviours. Appropriate strategies, which enable the novice teachers to control the class are predominant as they feel it is necessary to maintain a teaching environment that is well organized to support learning. Strategies such as 'moving student seating position', 're-arrange the desk and chairs' or 'do some exercises' to keep students quiet and behaviour under control (NT16, female) are some of the different ways NT16 coped. Other novice teachers talk about 'communicating with the students' about disruptive behaviours in the classroom (NT8, female).

Novice teacher-student role: Novice teachers feel that they apply control through use of appropriate classroom and behavior management approaches. Students' role is to cooperate with the teacher because of the control exerted. Importantly, the novice teachers perceive their roles in managing the classroom and behavioural issues to allow learning to occur as important.

\section{Conceptions of Competency 2: Methodical Preparation}

Intentions of the novice teachers: The focus of this conception is novice teachers' ability to maintain a classroom characterized by methodical preparation (lesson planning and organization of teaching resources) to control the classroom. Competency here entails 'proper preparation before class' (NT6, female) else she will feel 'out of control' and will not be able to be confident to start the class or end the class. There is fear that there will not be enough teaching activities and materials to use before class is over.

Strategy used to achieve this aim: Novice teachers talk about methodical planning as planning for the lesson and getting organized with teaching resources. Methodical planning entails writing a comprehensive lesson plan (NT6, female) or to plan the proper use of teaching aids and resources (NT15, female) as 'without it is asking for trouble' (NT6). Sometimes it is necessary to develop one's own teaching aid. NT1 (female) feels that positive student outcomes involve effective planning and it makes her happy to see her students enjoying the lesson.

Novice teacher-student role: Novice teachers feel that they apply control through behaviours such as planning a lesson to more complex notion of ensuring the appropriate use of teaching resources to influence student-learning outcomes. Nevertheless, the students' roles remain one of cooperation through a well-sequenced lesson. Here, novice teachers place great significance in their ability to be prepared for the responsibilities of teaching to cope with the many tasks and expectations placed on them as teachers. 


\section{Conceptions of Competency 3: Facilitate Learning}

Intentions of the novice teachers: In this conception, pedagogical knowledge and skills are competences that are perceived important to make learning happen. This is suggested by NT15 (female) where competency means '... someone who varies teaching with different techniques to make teaching and learning interesting'.

Strategy used to achieve this aim: Novice teachers see that one method of teaching in a lesson will not be enough to cater to the diverse learning abilities of their students. Using different methods of teaching become important to stoke students' interest as perceived by NT10 (male) as he needs to 'diversify my teaching'. Diversification of techniques involves NT10 using various multimedia technologies and to explore the best strategies to teach and attract students' attention and to make meaning for his students. To 'make teaching interesting' is reiterated by NT17 (female) because to her, it is about making her students engaged in their lesson and to ensure relevancy of what she is teaching. Quite importantly, most of the novice teachers reveal that they must make sure they understand the topic well, research if necessary and explore the subject matter well.

Novice teacher-student role: Novice teachers feel that they affect learning through applying their acquired knowledge and diversifying teaching practices to present subject content interestingly. Through this, students get interested and become involved in their learning and these contribute towards the students' achievement. An interesting finding derived from the data is that novice teachers feel happy when learning occurs, but also the notion that they feel competent when their students achieve.

\section{Conceptions of Competency 4: Understand and Empower Students}

Intentions of the novice teachers: A competent novice teacher is accountable to empower his/her students to take responsibility for their own learning. For this to happen, a teacher must first understand a student's strong points, the student's flaws and the student's potential under his/her charge. NT15 (female) surmises that a competent teacher also needs to be patient with the students especially pertaining to any learning issues encountered by the students.

Strategy used to achieve this aim: The focus of this conception is about not only having patience, but also understanding students under their charge such as knowing the issues and learning problems faced by the diverse students in the classroom (NT15, female). Novice teachers are also aware that getting upset with their misbehaving students are counterproductive. Instead, it is better to gauge why the behaviors occur in the first place. In the case of truancy, NT12 (female) feels that it is better to know why this behavior occurred, rather than disciplining a student without knowing the reason. Another important component of understanding the students under a teacher's charge is to be proactive, and not being complacent, in the involvement of the students' learning. NT12 (female) finds that taking interest in her students' learning is an important element towards being competent, importantly, 'don't ignore the student'.

Novice teacher-student role: Novice teachers feel that they must know what their students are capable of and what they should be able to achieve. Although managing 
behaviors is necessary, it is more important to know why those behaviors happen in the first place. In their roles as teachers, novice teachers believe that they must first understand and know how to deal with problematic students, have the patience and finally, take concern if the students are not performing. Students are able to perceive these expectations and are therefore motivated to improve and take responsibility for their own learning.

\section{Conceptions of Competency 5: Awareness of the Profession}

Intentions of the novice teachers: A competent novice teacher is able to assess themselves as teachers and to present an image of the profession. A competent professional teacher 'shows enthusiasm' and are motivated to 'attempt something better' (NT15, female). A competent teacher must also aspire to 'achieve a higher level of professionalism for his/her students' (NT1, female).

Strategy used to achieve this aim: Novice teachers project confidence and show integrity to meet their roles as teachers. Confidence to NT9 (female) is being 'courageous to try new things'. Challenges in schools must be met with fortitude, resilience and patience (NT16, female). Integrity of the teaching profession must be upheld, 'concentrate on our teaching and not do something else while in the classroom' (NT16, female). Elements such as possessing enthusiasm and having some elements of competitiveness in their work are also necessary, for example, 'a competent teacher must also be competitive with one's self', and 'show enthusiasm to be better' (NT15, female). According to NT15, these are signs of becoming a professional teacher. Being responsible, being punctual and versatile in carrying out the duties of a teacher is also cited as a part of becoming aware of the profession of teaching (NT15, female). Being able to change with the circumstance, being dynamic and adaptable is mentioned as elements of professional competency. Sacrificing for the sakes of his/her students is a part and parcel of a teacher's passion as an educator (NT2, female). In addition, being innovative and creative is also seen as the ability of the beginning teacher to accept change (NT1, female).

Novice teacher-student role: Novice teachers feel that competence is not necessarily the hours worked but by their willingness to 'do more than what is to be done' to achieve success in student learning. There is an awareness that they should behave accordingly as a part of the teaching profession. Specific novice teacher-student roles vary in accordance to the teaching and learning situation; novice teachers maintain a certain level of professional behaviors (a high standard of conduct, responsibility, attitude and work ethics) to encourage and support students to take more responsibility for their own leaning.

\section{DISCUSSION}

The conceptual map (Figure 1) provides a structural framework to illustrate the different categories of the conceptions of competency. It also indicates how these conceptions are logically related. According to Martön and Pong (2005), a conceptual map is drawn as a diagrammatic representation of the logical relationships between conceptions of a phenomenon. Overall, it can be seen that the novice teachers' competence exists in five 
different ways, from a less sophisticated view of competency to a more complex conceptions with the basic notion of competence as the 'success of student learning' being fundamental to all conceptions of competency. The qualitative differences between the various conceptions of competency and the relationship are hierarchical and can be classified as low, middle and high ranks of competency. The criteria used in ranking the three groups in this order are drawn from the distinctive characteristics in each of the five conceptions of competency. The conceptions of competency are seen as less sophisticated to more complex based on: i) Low: the 'technical view' of the teaching profession which are related to basic elements of teaching such as 'classroom and behavioral management' and 'methodical preparation' to control the learning environment; ii) Middle: the 'student centered view' of the teaching profession which are related to the elements of teaching which can 'facilitate learning' and to better 'understand and empower students'; and iii) High: the 'professional awareness' of the teaching profession which are related to novice teachers looking at themselves in the teaching role.

\begin{tabular}{llll}
\hline & Control & $\begin{array}{c}\text { Empower and facilitate } \\
\text { learning }\end{array}$ & $\begin{array}{c}\text { Assess each learning } \\
\text { situation and use best } \\
\text { approach }\end{array}$ \\
\hline
\end{tabular}

Figure 1

Novice teachers' conception of competency

In Figure 1, the conception of competency 1 and 2 are identified as low ranking conceptions of competency. The practice of competency focused on the technical aspects of the teaching profession. These represent the 'core' competency for any novice teachers starting out and are placed as a lower order competency. 'Core' competencies 
rely on controlling the classroom situation before any teaching can commence. There is little reliance upon resolving underlying problems that could have created an unruly classroom such as disciplinary issues among the students (Page, 2008). Appropriate controlling strategies are used with misbehaving students. The novice teachers acknowledge this as important as they begin their teaching roles as shown from the interviews. Similarly, being well prepared which refers to lesson planning and the use of appropriate teaching resources are vital aspects of control in the classroom as acknowledged by the novice teachers. During teacher preparation, these elements are taught quite aggressively as an emphasis for classroom control in the classroom. It would appear that novice teachers continue to embrace these elements as they assume responsibility for their own classrooms. Similarly, pre-service teachers during their practicum are more preoccupied with establishing and maintaining control over the learning environment (Goh \& Matthews, 2011). Although the technical aspects of classroom operation are important active phases of a new teacher as they need to assert authority on control, preparation and organization (Rahman, Scaife, Yahya, \& Jalil), too much emphasis will deflect the teacher from being more innovative in the learning environment. Novice teachers are advised to start using skills that are more able to encourage effective learning within the learning environment (Balli, 2009). The second perspective of the conceptual map, labeled as 'student centered view', placed as a middle order competency, shows that novice teachers now view teaching competency as more than just basic elements of classroom practices. Student learning and achievement take center stage. Novice teachers are starting to look beyond basic competent classroom practices. Their practices have now included other pedagogical methods to engage students in the learning process. Novice teachers report that they understood that one teaching method could not cater to the diverse learning abilities that exist in the classroom. Novice teachers realize that to reach out and 'to teach', they must use the correct pedagogical methods to encourage and motivate students.

Novice teachers in conceptions 3 and 4 are seen to possess a more definite focus on empowering their students in the learning process through an understanding of the diversity and differences in the learning abilities of their students. Understanding students being taught and empowering them entails a dual focus of first identifying students who face problems in their learning and then being patient and have empathy towards those problems. The conceptions are about taking interest in the students' achievement. Teachers who have reached these notions of competencies have been described in outcomes of various studies as 'effective teachers' (e.g. Walls, Nardi, von Minden, \& Hoffman, 2002; Walker, 2008). Just as conceptions of competency 1 and 2 highlight the contribution of classroom control and planning to the achievement of learning outcomes, conceptions of competency 3 and 4 argue that the pedagogical knowledge and skills and an understanding of the students being taught are important to empower students' achievement. Conception of competency 5, in which the novice teachers regard their competencies as having values of professionalism, is identified as a high ranked competency. This conception sees novice teachers as varying their practices in accordance with the needs of their students. The higher order competency shows practices that are prompted through reflection, informed professional judgement and a 
belief in novice teachers' own competences. Novice teachers with this conception also acknowledge that teaching is not static and therefore must be flexible to change to empower their students. They are able to see how these competences can contribute to develop their own professionalism within teaching. Novice teachers know that they need to exhibit confidence and enthusiasm for the teaching profession. Equally important to the professional image is to possess interest, positive attitudes, high work ethics and responsibility. It is also about being innovative and creative in a teaching situation (Wong, Chan, and Lai 2009). It would appear that the novice teachers, although new to the profession, are aware and capable of quite sophisticated views of competence.

\section{CONCLUSION}

This enquiry into the conceptions of competency of novice teachers makes an important contribution to existing knowledge, as there are so few in this area. It also carries some important implications for teacher educators and policy makers. Teacher educators should be cognizant of the diversity in practices of teachers and not limit that to say that there is just one acceptable conception of competency. Novice teachers enter the classroom with their own notion of what best practices to use in their classroom amassed from their own teaching preparation and experiences. It would then be unjust to these new teachers if they were judged against a staid competency evaluation without understanding what constitutes competency to them. A Conception of Competency 1 teacher believes he/she is doing the right thing in tightly controlling the classroom. It is the practice that he/she feels right to make learning happen. Nevertheless, this study does acknowledge that lower conceptions of competency, although historically valid, have its limitation in the sense that it retracts from providing students with a more engaging encounter in their studies. It generally fails to empower the students in their learning. Goh and Blake (2015) assert that in today's competitive environment, the need for teachers to be engaged in 'good teaching practices' and who can create a professional and effective learning environment cannot be overstated. 'Technical' competency is one in which novice teachers' practice is narrowly constrained in providing knowledge in a constricted and controlled environment. There is little evidence of problem solving and understanding the students within the learning environment. Teaching practice is aimed to be controlled with strategies employed to constrain behavior and chaos in the classroom. Novice teachers should use their substantive knowledge in solving problems. Doing that and consulting with a mentor teacher would negate the observed tendency to over-simplify the complexities of teaching. Teacher educators should take heed about Conceptions of Competency 1 and its existence among novice teachers. 'Technical' competencies are seen as inadequate when novice teachers are confronted with new challenges that lie beyond the bounds of teaching. If teacher educators wish to produce Conceptions of Competency 5, then they need to incorporate higher order competencies into their instructions. Teacher preparation institutions must be serious about developing teacher preparation programs. They must be positive in building and reinforcing successful and effective teacher preparation and practice opportunities that teachers need to support and promote education development in Malaysia (Goh \& Blake, 2015). Teacher educators cannot expect that because pre-service teachers have completed the requirements of the 
Bachelor of Education that these teachers are ready to embrace the expertise of teaching in a real situation. Ways must be sought to design learning strategies, which can present and familiarize pre-service teachers to the ways of teaching.

In Conceptions of Competency 3 and 4, novice teachers are focused on student achievement and to empower their students in the learning process. However, learning takes place when teachers reflect on their own practices and are able to make an evaluation of their student achievement (McCormack, Gore, \& Thomas, 2006). These can be seen in the higher rank of conception of competency (Conception of Competency 5) where novice teachers are able to make informed professional judgement and to acknowledge the context dependent nature of knowledge in their teaching practices. Novice teachers are able to gauge what qualities define a competent teacher within the context of their own experiences. They are able to think consciously and analytically about what works for them and possess the courage to 'investigate' with their teaching. The ways in which novice teachers reflectively view their own competencies as a result of his/her own 'self-assessment' can have the positive effect of helping them to examine and explore different ways to be a competent teacher (Rodman, 2010). Reflection is what allows us to learn from our experiences: it is an assessment of where we have been and where we want to go next (Wolf \& Siu-Runyan, 1996). It is heartening to see that the novice teachers in this study possessing analytical views of themselves as teachers. They have been open about facets of their teaching. Talking about their teaching finds novice teachers providing constructive suggestions towards improving aspects of their own teaching they are unhappy about. Schön (1983) explains that for a reflective teacher, there is no one right answer to doing something. Different solutions can be sought for different problems within the context of a classroom and will be more appropriate than others. Therefore, novice teachers with high order competencies are more ready to implement solutions to different learning contexts in the hope that these are more effective. Improving competency through some forms of monitoring procedures for the purpose of improving teacher quality which, hopefully, can translate to improved student outcomes is commendable. However, whether the implementation of competency-based standards can justifiably advance the quality of student outcomes and not overly prescribe a rigid teaching framework or constrict the teachers' creativity and autonomy is open to debate. Instead of judging novice teachers in a uniform way when they first set out to teach, these teachers should be helped to be aware of their own conception of competencies in their own work place and to develop a way to allow them to critically appraise their competencies. One of the ways is to give novice teachers the opportunity to talk about their teaching work and to capitalize on their own competency to develop ideas around the conceptions that they value. In this study, novice teachers' focuses are about achieving their aims of competency in strategically different ways and in each of these ways, the novice teachers' strategies are critical to their understanding of the novice teacher-student roles.

In conclusion, this study has extended the literature of novice teachers' competencies using a phenomenographic approach to describe the variation that exists in the way novice teachers conceive of their competency. Firstly, teacher preparation needs to acknowledge that this variation exists in teachers' conceptions of their own competency. 
Equally important, teacher education needs to provide opportunities to learn from these novice teachers to better design and develop teacher education programs more suited to the existing conceptions of novice teachers. A standards process may be guilty of eliminating some forms of effective teaching while endorsing other forms and homogenizing all teaching and learning activities (Goh \& Blake, 2015). This study has taken time to collect data and taken time to listen to novice teachers' views during their early years of teaching. This patience has provided unexpected and valuable insights into their conceptions of competency which cannot be obtained through inventories or observations.

\section{REFERENCES}

Admiraal, W., \& Berry, A. (2015). "Video narratives to assess student teachers' competence as new teachers." Teachers and Teaching. doi:10.1080/13540602.2015.1023026

Balli, S.J. (2009). Making a difference in the classroom: Strategies that connect with students. Maryland: Rowman \& Littlefield Education.

Darling-Hammond, L., Newton, S. P., \& Wei, R. C. (2013). "Developing and assessing beginning teacher effectiveness: The potential of performance assessments." Educational Assessment, Evaluation, and Accountability, 25(3): 179-204. doi:10.1007/s11092-013-9163-0

Rahman, F.A., Scaife, J., Yahya, N.A., \& Jalil, H.A. (2010). Knowledge of diverse learners: implications for the practice of teaching. International Journal of Instruction, 3(2), 83-96.

Fatiha, S., Abd Razak, Z., \& Shanina, S.A.S. (2013). "Novice teachers' challenges and survival: Where do Malaysian ESL teachers stand?" American Journal of Educational Research, 1(4), 119-125. doi: 10.12691/education-1-4-2

Feiman-Nemser, S. (2001). "From preparation to practice: Designing a continuum to strengthen and sustain teaching." Teacher College Record, 103(6), 1013-1055.

Goh, P.S.C., and Matthews, B. (2011). "Listening To the concerns of student teachers In Malaysia during teaching practice." Australian Journal of Teacher Education, 36(3), 92-103. doi: 10.14221/ajte.2011v36n3.2

Goh, P.S.C., \& Blake, D. (2015). "Teacher preparation in Malaysia: Needed changes." Teaching in Higher Education, 20(5), 469-480. doi: 10.1080/13562517.2015.1020780

Halverson, R. Kelly, C., \& Kimball, S. (2004). "How principals make sense of complex artifacts to shape local instructional practice." In Educational administration, policy, and reform: Research and measurement, edited by W.K. Hoy and C. G. Greenwich, 153-188. CT: George F Johnson.

Larsson, J., \& Holmstrom, I. (2007). "Phenomenographic or phenomenological analysis: does it matter? Examples from a study on anesthesiologists' work." 
International Journal of Qualitative Studies on Health and Well-being, 2(1), 55-64. doi: 10.1080/17482620601068105

Malaysia first in region to adopt benchmark for educators. (2009). The Star Online, December 3.

http://thestar.com.my/news/story.asp?file=/2009/12/3/nation/5225720\&sec=nation

Martön, F., and Pong, W.Y. (2005). "On the unit of description in phenomenography." Higher Education Research and Development, 24(4), 335-348. doi: 10.1080/07294360500284706

McCormack, A., Gore, J., \& Thomas, K. (2006). "Early career teacher professional learning." Asia-Pacific Journal of Teacher Education, 34(1), 95-113. doi: 10.1080.13598660500480282

Page, M.L. (2008). You can't teach until everyone is listening: Six simple steps to preventing disorder, disruption, and general mayhem. California: Corwin Press.

Rodman, G. J. (2010). "Facilitating the teaching-learning process through the reflective engagement of pre-service teachers." Australian Journal of Teacher Education, 35(2), 20-34.

Sandberg, J., and Pinnington, A.H. (2009). "Professional competence as ways of being: An existential ontological perspective." Journal of Management Studies, 46(7), 11381170. doi: 10.1111/j.1467-6486.2009.00845.x

Schön, D.A. (1983). The reflective practitioner. New York: Basic Books.

Serafini, F. (2002). "Possibilities and challenges: The national board for professional teaching standards." Journal of Teacher Education, 53(4), 316-327. doi: 10.1177/0022487102053004004

Stokking, K., Leender, F., De Jong, J., \& Van Tarwijk, J. (2003). "From student to teacher: Reduce practice shock and early dropout in the teaching profession." European Journal of Teacher Education, 26(3), 328-350. doi: 10.1080/026197603200012817

Sykes, G., Bird T., \& Kennedy, M. (2010). "Teacher education: its problems and some prospects." Journal of Teacher Education, 61(5), 464-476. doi: 10.1177/0022487110375804.

Tuinamuana, K. (2011). "Teacher professional standards, accountability, and ideology: Alternative discourses.” Australian Journal of Teacher Education, 36(12), 72-82.

Walker, R.J. (2008). "Twelve characteristics of an effective teacher: A longitudinal, qualitative, quasi-research study of in-service and pre-service teachers' opinions." Educational Horizons, 87(1), 61-68.

Walls, R.T., Nardi, A.H., von Minden, A.M., \& Hoffman, N. (2002). "The characteristics of effective and ineffective teachers." Teacher Education Quarterly, 29(1), 39-48. 
Wolf, K., \& Siu-Run yan, Y. (1996). "Portfolio purposes and possibilities." Journal of Adolescent and Adult Literacy, 40(1), 30-37.

Wong, A.K.Y., Chan, K.W., \& Lai, P.Y. (2009). "Revisiting the relationships of epistemological beliefs and conceptions about teaching and learning of pre-service teachers in Hong Kong.” The Asia-Pacific Educational Researcher, 18(1), 1-19.

\section{Turkish Abstract}

\section{Yaşanmış Tecrübe: Deneyimsiz Öğretmenlerin Yeterlik Algıları}

Bu çalışma 18 deneyimsiz öğretmenin sınıflarındaki performanslarıyla ilgili yeterlik algılarının ne olduğunu içeriden ve dışarıdan bir bakış açısıyla bakarak bir ilişki kurmayı amaçlamıştır. Bu çalışmada deneyimsiz öğretmenlerin okullarında yaşadıkları tecrübelerle ilgili düşünceleri onların yeterlik algılarını oluşturmaktadır. Deneyimsiz öğretmenlerin yeterlik hedeflerine ulaşma konusunda izleyecekleri stratejik yollar ve bu yollardaki öğretmen ve öğrenci rolleri kritik bir öneme sahiptir. Bu konuda 5 düşünce tanımlanmıştır: Öğretmenler olarak sınıfı ve öğrenci davranışlarını kontrol etmek, derse yöntemsel hazırlık yapmak, pedagojik bilgi ve yeteneklerini kullanmak, öğrencilerin kendi kendine öğrenmelerine izin vermek ve onları anlamak, öğrencilerin farkında olmak. Yeterlik algısı grafiksel olarak gösterilmiş ve karmaşıklı düzeyine göre tartışılmıştır. Buna göre deneyimsiz öğretmenlerin yeterlik algılarını ifade etme yollarında farklılık olduğu bulunmuştur. Öğretmen yetiştiren eğitimciler öğretmenlerin ders içi uygulamalarının çeşitlilği konusunda bilinçli olmalı ve kabul edilebilir tek bir yeterlik algısı söylemi olduğu konusunda kendilerini sınırlamamalıdır.

Anahtar Kelimeler: deneyimsiz öğretmenler, Malezya öğretmen eğitimi, yeterlik algısı, profesyonel uygulama, profesyonel katılım

\section{French Abstract \\ Expérience Vécue: les Perceptions de Compétence de Professeurs de Novice}

Cette étude comble le fossé d'une perspective d'initié d'étranger de compétence et capture l'essence de ce qui constitue la compétence parmi 18 professeurs de novice dans leurs propres actions exécutées dans des salles de classe réelles. Dans cette étude, les aspects pertinents des professeurs de novice 'la vivre-expérience' à leurs écoles composent leurs conceptions de competence. La conversation des professeurs de novice de la réalisation de leurs buts de compétence de façons stratégiquement différentes et de façon de ces façons, les stratégies des professeurs de novice sont critiques à leur compréhension des rôles d'étudiant-professeur de novice. Cinq conceptions identifiées sont : contrôle la salle de classe et le comportement d'étudiants, la préparation méthodique, utilise la connaissance pédagogique du son et des compétences, comprend et autorise leurs étudiants à prendre la charge de leur propre apprentissage et une conscience d'entre eux comme des professeurs. Les conceptions de compétence sont représentées schématiquement et sont discutées en ce qui concerne les niveaux de complexité. La variation existe dans la façon dont les professeurs de novice conçoivent de leur compétence. Les éducateurs de professeur devraient être informés de la diversité dans les pratiques de professeurs et pas la limite que dire qu'il y a juste une conception acceptable de compétence.

Mots Clés: professeurs de novice, enseignement de professeur Malais, les conceptions de compétence, pratique professionnelle, engagement professionnel 


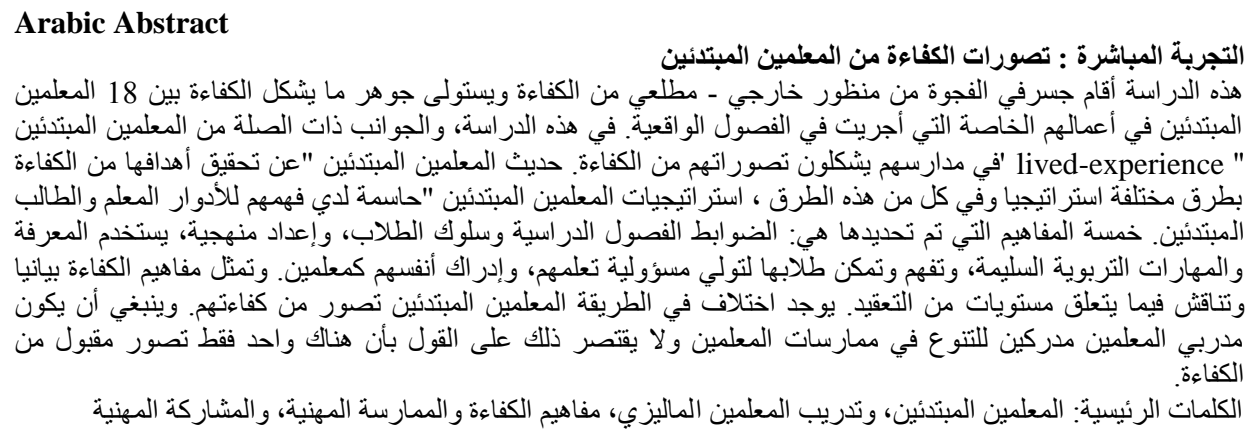

\section{German Abstract}

Lebte Erfahrung: Die Wahrnehmung der Kompetenz von Junglehrern

Diese Studie überbrückt die Kluft einer Außenseiter-Insider-Perspektive der Kompetenz und erfasst das Wesen dessen, was die Kompetenz von 18 Anfängerlehrern in ihren eigenen Handlungen in realen Klassenzimmern ausmacht In dieser Studie bilden relevante Aspekte des Erlebnisses der Anfängerlehrer in ihren Schulen ihre Kompetenzbegriffe.. Anfänger Lehrer, die über die Erreichung ihrer Ziele der Kompetenz auf strategisch unterschiedliche Weise und in jeder dieser Möglichkeiten, die Anfänger Lehrer Strategien sind entscheidend für ihr Verständnis der Anfänger Lehrer-Schüler Rollen. Fünf Identifierte Konzepte sind: kontrolliert das Klassenzimmer und das Verhalten der Schüler, methodische Vorbereitung, verwendet fundierte pädagogische Kenntnisse und Fähigkeiten, versteht und befähigt ihre Schüler, ihr eigenes Lernen zu übernehmen und ein Bewusstsein für sich selbst als Lehrer. Die Begriffe der Kompetenz sind schematisch dargestellt und werden in Bezug auf Komplexitätsniveaus diskutiert. Variation besteht in der Art und Weise, wie Anfänger Lehrer ihre Kompetenz konzipieren. Lehrer Pädagogen sollten bewusst sein, die Vielfalt in der Praxis der Lehrer und nicht beschränken, dass zu sagen, dass es nur eine akzeptable Konzeption der Kompetenz.

Schlüsselwörter: anfängerlehrer, Malaysische lehrerausbildung, kompetenzkonzeptionen, berufspraxis, professionelles engagement

\section{Malaysian Abstract \\ Tinggalkan Pengalaman: Persepsi Kompetensi Guru Novis}

Kajian ini merapatkan jurang perspektif orang luar-orang dalam terhadap kecekapan dan menggambarkan intipati apa yang menjadi kompetensi 18 guru novis dalam tindakan mereka sendiri yang dilakukan di dalam kelas sebenar. Dalam kajian ini, aspek yang berkaitan dengan guru-guru baru " hidup-pengalaman 'di sekolah-sekolah mereka membentuk konsep kompetensi mereka. 'Bercakap tentang mencapai matlamat mereka kompetensi dengan cara yang strategik yang berbeza dan dalam setiap cara ini, guru-guru baru strategi adalah penting untuk pemahaman mereka tentang peranan guru-murid. Lima konsep yang dikenal pasti adalah: kawalan bilik darjah dan tingkah laku pelajar, penyediaan teratur, menggunakan pengetahuan pedagogi dan kemahiran, 
memahami dan memberi kuasa kepada pelajar-pelajar mereka untuk mengambil alih pembelajaran mereka sendiri, dan kesedaran tentang diri mereka sebagai guru. Konsep kecekapan diwakili rajah dan dibincangkan berkenaan dengan tahap kerumitan. Perubahan wujud dalam cara guru baru memperoleh kecekapan mereka. Sebagai pendidik guru harus menyedari kepelbagaian dalam amalan guru dan tidak menghadkan bahawa untuk mengatakan bahawa terdapat hanya satu konsep yang boleh diterima sebagai kompetensi.

Kata Kunci: guru baru, pendidikan guru Malaysia, konsep kecekapan, amalan profesional, penglibatan professional

\section{Russian Abstract \\ Исследовано: Восприятие Компетентности Неопытных Учителей}

Это исследование составляет аутсайдер-инсайдерскую точки зрения компетентности на правомочность среди 18 неопытных учителей классах. В этом исследовании, дан опыт неопытных учителей в школах и их представления о компетентности. Обсуждение неопытных учителей о достижении своих целей компетентности по-стратегически разный пути и в каждом из этих способов, стратегии послушник учителей имеют решающее значение для их понимания и начинающих учителей и студентов ролей. Пять выявленных концепций являются: управление в классе и поведение студентов, методическая подготовка, использование звука в педагогических знанях и уменях, понимание и расширение прав и возможностей своих студентов взять на себя ответственность за их собственное обучение, и осознание себя в качестве учителей. Представления о компетентности связано с уровнем сложности. Вариация существует в пути начинающих преподавателей в их компетенции. Учителя должны познавать и релизовавать разнообразие в практики учителей, а не ограничивать только одной приемлемой концепцией компетенции.

Ключевые Слова: начинающие преподаватели, Малазийское педагогическое образование, концепции компетентности, профессиональная практика, профессиональное сотрудничество 